\title{
Test meal for assessing intraluminal phase of absorption in childhood
}

\author{
J. P. K. McCOllum, D. P. R. MUlleR, AND J. T. HARRIES \\ From the Institute of Child Health, and The Hospital for Sick Children, London
}

SUMMARY A test meal for assessing the intraluminal phase of absorption in childhood has been validated. 132 test meals were administered to 110 patients aged 2 weeks to 18 years (mean age $4 \cdot 3$ years). 10 children with suspected malabsorption, who were proven to be normal after extensive investigation, constituted the control group. The activities of pancreatic enzymes, and the total and individual bile salt concentrations are presented for the control subjects, and pancreatic enzyme levels in this group are compared with those seen in children with pancreatic insufficiency (cystic fibrosis). The test meal has been designed so that it can be administered to children with suspected gluten, cows' milk, or disaccharide intolerance. The control data provided a basis for the interpretation of information obtained from the application of such a test meal to the clinical investigation of children with suspected malabsorption.

In clinical practice there are essentially two ways of assessing the function of a digestive organ. Firstly by stimulation with intraluminal nutrients, and secondly by the subcutaneous or intramuscular (e.g. ametazole to stimulate gastric acid secretion) or intravenous (e.g. secretin and cholecystokininpancreozymin to stimulate pancreatic secretions) administration of a known stimulant.

The former approach provides a physiological stimulus, whereas the latter provides information regarding the maximal secretory capacity, which may not be relevant to the clinical problems facing the physician in individual patients. There is a limited amount of data on the response of the pancreas and gallbladder to intravenous secretin and cholecystokinin-pancreozymin in childhood (Hadorn, 1972; Zoppi et al., 1972), but there is no systematic information on the response to a standardized test meal. In this paper we have validated a modification of the Lundh test meal (Lundh, 1962) to investigate the intraluminal phase of absorption in children.

\section{Subjects and methods}

132 test meals were administered to 110 patients (64 males, 46 females) aged 2 weeks to 18 years (mean age $4 \cdot 3$ years). The patients fell into the following diagnostic groups: protracted diarrhoea $38(35 \%)$, cystic fibrosis $7(6 \%)$ other pancreatic disorders 12 (11\%), intestinal resections 8 (7\%), Crohn's disease

Received 4 April 1977
$3(3 \%)$, liver disease $2(2 \%)$, hypobetalipoproteinaemia $2(2 \%)$, and a miscellaneous group of gastrointestinal disorders $28(25 \%) .10$ children $(9 \%)$ with suspected malabsorption, who were proven to be normal after extensive investigation, constituted the control group.

The liquidized test meal contained carbohydrate $(4 \%)$ in the form of glucose, protein $(4 \%)$ as comminuted chicken, and fat $(4 \%)$ as corn oil. This particular composition enabled it to be administered to children who were sensitive to cows' milk protein or gluten, as well as to those who were intolerant of disaccharides, without danger of precipitating gastrointestinal symptoms. After an overnight fast in older children, a 4-hour fast in young infants, or a fast appropriate only to the interval between feeds in very sick infants, the patients were sedated with intramuscular trimeprazine* $(1 \mathrm{mg} / \mathrm{kg})$. A nasogastric tube was passed for administering the test meal $(30 \mathrm{ml} / \mathrm{kg}$ up to a miximum of $240 \mathrm{ml})$. The collecting tube, a single lumen PVC tube weighted at its end with a small mercury bag, was passed into the fourth part of the duodenum under fluoroscopic control. Administration of the meal via a nasogastric tube was preferred since it was very difficult to persuade children to ingest the test meal with the collecting tube already positioned; moreover, at the onset of the study several children vomited the meal when given by mouth. The nasogastric tube also allowed

*Trimeprazine is no longer commercially available, and we currently use chlorpromazine $(1 \mathrm{mg} / \mathrm{kg})$. 
samples of gastric juice to be obtained during the procedure. Initially, fasting and six 20-minute postprandial collections of juice were made by siphonage on ice, and pancreatic enzymes and bile salts were measured on each sample. Subsequently, however, a 2-hour postprandial pool was collected and pancreatic enzymes and bile salts determined on an aliquot of the pool; this is considered further in the results section.

Lipase was assayed titrimetrically using glycerol tributyrate as substrate (Erlanson and Borgstrom, 1970), trypsin by a modification of the titrimetric procedure of Wiggins (1967) using p-tosyl-1-arginine methyl ester (TAME) as substrate, amylase by the method of Ceska et al. (1969), and esterase was determined colorimetrically using p-nitrophenyl acetate as substrate (Erlanson, 1970). Each enzyme remained stable in juice stored at $-20^{\circ} \mathrm{C}$ for periods up to 6 months.

Total bile salt concentrations were determined by the enzymatic procedure of Iwata and Yamasaki (1964) after extraction from the juice on Amberlite XAD resin (Makino and Sjövall, 1972). Individual bile salt concentrations were determined by the same method after separation by thin layer chromatography using the solvent system of Hofmann (1964); amyl acetate/propionic acid/n-propanol/water $(4: 3: 2: 1 \mathrm{v} / \mathrm{v})$. Both procedures gave consistent recoveries of greater than $85 \%$.

\section{Results}

Ten $(8 \%)$ of the 132 intubations were failures; 3 because the tube did not enter the duodenum, 2 because the tube returned to the stomach after administration of the test meal, 5 children vomited, and in 2 patients the tube blocked.

The Fig. shows the typical pattern of enzyme activity and total bile salt concentrations in fasting and 20-minute samples of postprandial juice in a control subject. Pancreatic enzyme activity and total bile salt concentrations were commonly low and sometimes undetectable in fasting juice; thereafter a biphasic response was observed.

The activities of pancreatic enzymes and total and individual bile salt concentrations in pooled 2-hour postprandial juice from control children, and pancreatic enzyme activities in a group of children with cystic fibrosis are shown in the Table. In contrast to the control subjects, the patients with cystic fibrosis had very low levels of trypsin, lipase, and esterase. The mean of the volumes of postprandial juice was $55 \mathrm{ml}$ (range 8-160 ml). In children under the age of one year the mean was $30 \mathrm{ml}$ (range 8-100 ml).

\section{Discussion}

This study has validated a method for investigating the intraluminal phase of absorption in children with suspected malabsorptive states; the procedure is safe and simple, and can be applied to patients with gluten, cows' milk protein, or disaccharide intolerance. The Fig. shows the typical pattern of enzyme activity and bile salt concentrations that were found during the course of the test meal. The low or absent levels in fasting duodenal juice were a frequent finding. Levels rose to a peak at either 20 or 40 minutes after administration of the meal, and a second peak usually occurred at 80 or 100 minutes. For these reasons the procedure was standardized

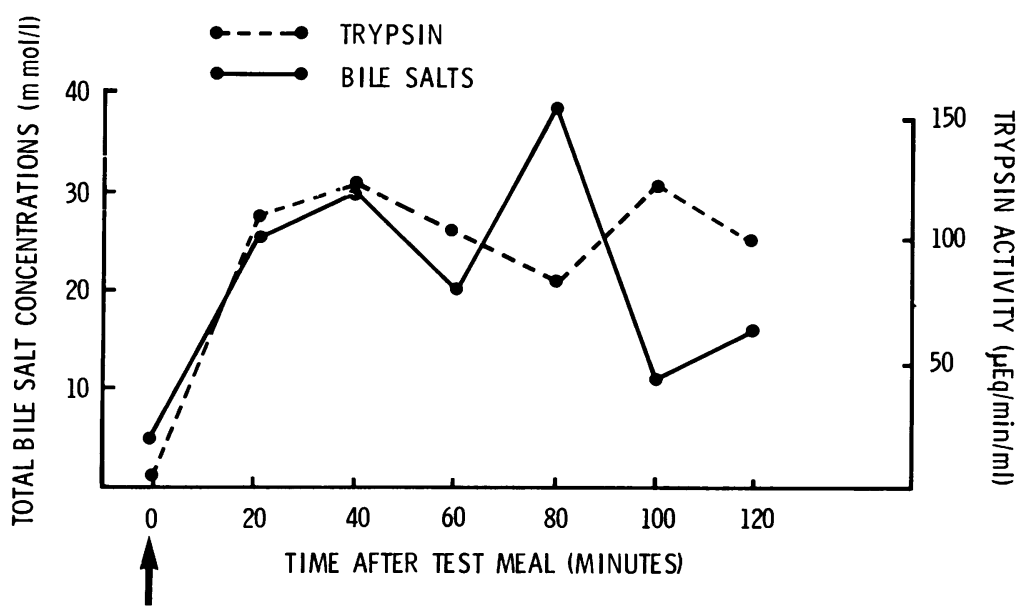

Fig. Typical pattern of enzyme activity and total bile salt concentrations in fasting and 20-minute samples of postprandial duodenal juice. 
Table Activities of pancreatic enzymes and total and individual bile salt concentrations (mean and range) in control children* and in patients with cystic fibrosis after a test meal

\begin{tabular}{|c|c|c|c|c|}
\hline & $\begin{array}{l}\text { Trypsin } \\
(\mu E q / \min \text { per } m l)\end{array}$ & $\begin{array}{l}\text { Amylase } \\
(I U / m l)\end{array}$ & $\begin{array}{l}\text { Lipase } \\
(\mu E q / \text { min per } m l)\end{array}$ & $\begin{array}{l}\text { Esterase } \\
\text { ( } \mu \mathrm{mol} / \mathrm{min} \text { per } \mathrm{ml})\end{array}$ \\
\hline \multirow[t]{2}{*}{$\begin{array}{l}\text { Controls } \\
\text { Cystic fibrosis } \dagger\end{array}$} & $\begin{array}{l}46 \cdot 4(29 \cdot 4-83 \cdot 3) \\
2 \cdot 4(0 \cdot 7-7 \cdot 2)\end{array}$ & $\begin{array}{l}34(8 \cdot 2-125) \\
\mathrm{ND}\end{array}$ & $\begin{array}{l}860(270-1920) \\
7(4-10)\end{array}$ & $\begin{array}{l}1 \cdot 6(0 \cdot 57-3 \cdot 30) \\
0 \cdot 10(0 \cdot 01-0 \cdot 33)\end{array}$ \\
\hline & $\begin{array}{l}\text { Total bile salt } \\
\text { concentrations } \\
(\mathrm{mmol} / \mathrm{I})\end{array}$ & $\begin{array}{l}\text { Ratio of glycine: taurine } \\
\text { conjugated bile salts }\end{array}$ & \multicolumn{2}{|r|}{$\begin{array}{l}\text { Dihydroxy bile salts } \\
(\% \text { of total) }\end{array}$} \\
\hline Controls & $7 \cdot 3(3 \cdot 0-16 \cdot 0)$ & $2 \cdot 8: 1 \cdot 0(1 \cdot 3: 1 \cdot 0-4 \cdot 0: 1 \cdot 0)$ & \multicolumn{2}{|r|}{$60 \cdot 0(53 \cdot 0-70 \cdot 0)$} \\
\hline
\end{tabular}

*Children with suspected malabsorption who were proven to be normal after extensive investigation, aged 16 months to 16 years $(n=10)$. tAged 1 month to 15 years $(n=7)$.

ND $=$ not done.

for routine clinical use, and a 2-hour pooled collection of postprandial duodenal juice was obtained from each patient.

In addition to assessing pancreatic function and intraluminal bile salt concentrations, the procedure can be used to assess gastric function (e.g. $p \mathrm{H}$, 'gastric' lipase activity); the bacterial, parasitic, and viral flora of the proximal small gut may also be studied.

J.P.K.McC. acknowledges the financial support of The Wellcome Trust. We also acknowledge the support of the National Fund for Research into Crippling Diseases, and the Medical Research Council.

\section{References}

Ceska, M., Birath, K., and Brown, B. (1969). A new and rapid method for the clinical determination of $\alpha$-amylase activities in human serum and urine. Optimal conditions. Clinica Chimica Acta, 26, 437-444.

Erlanson, C. (1970). p-nitrophenylacetate as a substrate for a carboxyl-esterhydrolase in pancreatic juice and intestinal content. Scandinavian Journal of Gastroenterology, 5, 333-336.
Erlanson, C., and Borgström, B. (1970). Tributyrine as a substrate for determination of lipase activity of pancreatic juice and small intestinal content. Scandinavian Journal of Gastroenterology, 5, 293-295.

Hadorn, B. (1972). Diseases of the pancreas in children. Clinics in Gastroenterology, 1, 125-146.

Hofmann, A. (1964). New Biochemical Separations, p. 362. Ed. by A. T. James and L. J. Morris. Van Nostrand, Princeton.

Iwata, T., and Yamasaki, K. (1964). Enzymatic determination and thin-layer chromatography of bile acids in blood. Journal of Biochemistry (Tokyo), 56, 424-431.

Lundh, G. (1962). Pancreatic exocrine function in neoplastic and inflammatory disease: a simple and reliable new test. Gastroenterology, 42, 275-280.

Makino, I., and Sjövall, J. (1972). A versatile method for analysis of bile acids in plasma. Analytical Letters, 5, 341-349.

Wiggins, H. S. (1967). Simple method for estimating trypsin. Gut, 8, 415-416.

Zoppi, G., Andreotti, G., Pajno-Ferrara, F., Njai, D. M., and Gaburro, D. (1972). Exocrine pancreas function in premature and full term neonates. Pediatric Research, 6, 880-886.

Correspondence to Dr. J. T. Harries, Institute of Child Health, 30 Guilford Street, London WC1N $1 \mathrm{EH}$. 